\title{
Are Socially Responsible Investment Markets Worldwide Integrated?
}

\author{
Eduardo Roca* \\ Department of Accounting, Finance and Economics \\ Griffith Business School \\ Griffith University, Nathan, Queensland, Australia 4111 \\ Tel: 6173735 7583, Fax: 61737353719 \\ Email: E.Roca@griffith.edu.au \\ (Corresponding author) \\ Victor S.H. Wong \\ Department of Accounting, Finance and Economics \\ Griffith Business School \\ Griffith University, Nathan, Queensland, Australia 4111 \\ Tel: 6173735 5167, Fax: 61737353719 \\ Email: V.Wong@griffith.edu.au \\ Gurudeo Anand Tularam \\ Faculty of Science, Engineering, Environment and Technology \\ Griffith University, Nathan, Queensland, Australia 4111 \\ Tel: 6173735 3522, Fax: 61737356717 \\ Email: A.Tularam@griffith.edu.au
}

\section{Abstract}

Socially Responsible Investment (SRI), as a form of investment, has grown very substantially over the last three decades and now commands significant participation from huge institutional investors. Due to the additional non-financial criteria that it seeks to fulfil, SRI suffers from a limited investment universe. International diversification therefore provides an important opportunity to SRI investors in alleviating this problem. The magnitude of the benefits from international diversification depends on the extent of linkages between SRI markets. International portfolio diversification theory posits that the more (less) integrated the markets are, the less the benefits from international diversification. This paper therefore examines this issue. It investigates the extent and structure of equity price interdependence among the Socially Responsible Investment (SRI) markets of Australia, Canada, Japan, UK and US over the period 1994-2010. The results show that the markets are significantly interdependent and have become more so over the years. The US and the UK are the markets most linked to other markets while Canada and Australia are the most influential markets. Although the markets are significantly integrated, the level of integration is still at a low level. Hence, there are still benefits to be gained by SRI investors from international diversification.
JEL CLASSIFICATION
: C32, G15, Q56
KEYWORDS
: Socially responsible investment, integration, vector autoregression, international diversification, price interdependence
RUNNING HEAD
: World Socially Responsible Investment Markets Integration

\footnotetext{
${ }^{*}$ We are grateful for comments received from the two referees of this paper and from the participants of the $16^{\text {th }}$ Conference on the Theories and Practices of Securities and Financial Markets held on December 5-8, 2008 at National Sun Yat-Sen University, Kaohsiung, Taiwan, and the Annual International Conference on Finance, Accounting, Investment and Risk Management 2009 held at the Gold Coast, Australia. We also thank Ms Jane Li for providing research assistance and comments to this paper.
} 


\section{INTRODUCTION}

SRI is a form of investment that combines the pursuit of financial returns and non-financialsuch as environmental, governance and social considerations. It is claimed that the pursuit of non-financial factors provide SRI investors with extra utility or satisfaction. There is also the belief by SRI investors that ESG factors materially affect the returns in a positive way that can lead to lower cost arising form the avoidance or minimisation of environmental and reputational risk, better management, and better customer satisfaction that leads to higher revenues (Renneboog, et al., 2006; 2008). However, due to these extra considerations, there is a reduction in the investment universe of the SRI investors which results in a more limited diversification for SRI investors.

One way to alleviate this problem of limited diversification is for SRI investors to undertake international diversification across SRI markets worldwide. This is now an opportunity that is available to SRI aficionados. SRI is now a very significant form of investment around the world. Over the past three decades, SRI has grown tremendously and expanded globally ${ }^{1}$. This massive growth in SRI is being fuelled by the increasing involvement of large institutional investors such as pension and mutual funds, and other traditional financial services providers. Global organisations such as the UN Principles of Responsible Investment, UN Environmental Programme, Global Compact, among others, have also significantly boosted the growth of SRI as these organisations now command the membership of huge global financial institutions and institutional investors which pledge to promote SRI. The interest and support for SRI has also generated the creation of specific share indices such as the Dow Jones Sustainable Index (DJSI) and FTSE4GOOD as well as specialised research houses such, among others, Morningstar and Sustainable Investment Research Institute (SIRIS) to support the growth of the industry.

A crucial factor that determines the benefits for SRI investors from international diversification is the extent of integration or linkages among SRI markets. According to

\footnotetext{
1 SRI assets were worth US\$2.71 trillion in the United States, as reported by the Social Investment Forum (2007), and C $\$ 503$ billion (US\$471 billion) ${ }^{1}$ in Canada based on information from the Canadian Social Investment Organisation (2006). In Europe, the UK is the leading SRI market with assets valued at $€ 781$ billion (US\$1.17 trillion) based on data from the European Social Investment Forum (2006). In Asia, the leading SRI market is Japan with up to ¥840 billion (US\$7.3 billion) ${ }^{1}$ worth of SRI assets (SIF-J, 2007). Finally, Australia is the fastest growing SRI market, with total assets of A\$19.4 billion (US\$17.3 million) as reported by the Responsible Investment Association Australasia (2007).
} 
international portfolio diversification theory, the lower (higher) the extent of linkages between markets, the greater (smaller) the benefits from international diversification. However, there is no clear understanding yet as regards the extent of linkages among SRI markets worldwide. There are now a number of studies on SRI which have investigated the following aspects of SRI - performance (Luther, et al., 1992; Hamilton, et al., 1993; Gregory, et al., 1997; Russo and Fouts, 1997; Dibartolomeo and Kurtz, 1999; Statman, 2000; Orlitzky, et al., 2003; Bauer, et al., 2005; Kreander, et al., 2005; Hong and Kacperczyk, 2006; Bauer, et al., 2007; Edmans, 2007), ratings (Angel and Rivoli, 1997; Lee and Ng, 2002; Guenster, et al., 2005) and screenings (Guerard, 1997). None of these studies, however, have focused on the linkages or spill-over between SRI markets. This paper therefore addresses this gap in the SRI literature. It analyses the extent of integration between the SRI markets of Australia, Canada, Japan, UK and US. In particular, it examines the extent, speed and duration of interaction among these SRI markets

This paper therefore provides knowledge on the extent of integration among SRI markets. As previously mentioned, this knowledge is highly important to SRI investors if they are to diversify internationally across SRI markets. Additionally, this knowledge is also of value to regulators. If SRI markets are found to be closely linked or integrated, then there is the risk of shocks in one SRI market spilling over to another SRI market - creating contagion risk which regulators will have to address. Academically, this paper contributes to the literature on SRI. As far as we know, this is the first SRI study on this issue.

In addition to extending the SRI literature, the present study also contributes to the literature on international financial market integration. There are now a voluminous number of studies which have examined the issue of international integration among equity, bonds, and money markets (Panopolou and Pantelidis, 2009; Chi, et al., 2006; Click and Plummer, 2005; Roca, 1999). However, there is no consensus among these studies as to whether markets are integrated or not. Some studies have found that markets are integrated while other studies found the opposite depending on the type of market studied, and the time period and data used. This paper therefore provides further evidence on the issue of financial integration bases on a market - i.e. SRI, which is deemed to be different from those which have been studied by the existing literature.

Studies on equity market integration have primarily examined the following issues: 
(a) whether equity markets are integrated or segmented.

(b) whether the linkage between equity markets are stable or unstable.

(c) whether there are groupings among markets in terms of linkages.

(d) the manner of interaction among equity markets - which markets are influential, how one market affects another market, and the speed of interaction among markets.

As mentioned earlier, the results of these studies are mixed. Some have concluded that equity markets are integrated (see, for instance, Agmon, 1972; Ripley, 1973; Hillard, 1979; Ibbotson et al., 1982; Jaffe and Westerfield, 1985; Schollhammer and Sand, 1987; Wheatley, 1988; Hamao, et al., 1990; Espitia and Santamaria, 1994, among others). Other studies reported that equity markets are segmented (see, for instance, Grubel, 1968; Makridakis and Wheelwright, 1974; Adler and Dumas, 1983; Jorion and Schwartz, 1986; Levy and Lerman, 1988; Dwyer and Hafer, 1988; Jorion, 1989; Smith, et al., 1995). With respect to the stability of equity market linkages, again, the results of previous studies are divergent. Some studies found equity market linkages to be stable (e.g., Panton, et al., 1976; Philippatos, et al., 1983; Goodhart, 1988 among others). Others claim that linkages among equity markets are unstable (see, for instance, Maldonado and Saunders, 1981; Roll, 1989a and 1989b).

A number of studies have examined the manner of interaction among equity markets in terms of the influence of one market over the other, the manner of response of markets to influences coming from other markets, and the speed by which shocks or volatility from one market is transmitted to other markets. There is overwhelming evidence that the US equity market is the most influential stockmarket in the world (see, for instance, Khoury, et al., 1987; Schollhammer and Sand, 1987; Fischer and Palasvirta, 1990; Espitia and Santamaria, 1994).

Considering that the Japanese equity market is the second largest in the world (in fact, in certain years in the past, it was the biggest), there is the expectation that it would at least exert significant influence on other markets, particularly in the Asia Pacific. The results from previous studies do not provide a clear answer. Lee (1992), after analysing the relationship between the stockmarkets of Japan, Korea, Taiwan, Hong Kong, and Singapore using monthly data from January 1970 to December 1989, concluded that Japan is not an influential market. Becker, et al. (1990) and Jaffe and Westerfield (1985) reported that the Japanese equity market had only a small impact on the United States stockmarket during the period 1985-1988. On the other hand, Jeon and Von Furstenberg (1990) and Hamao, et al. (1990) had found the Japanese market to be less interdependent with the US stockmarket since the 
crash of October 1987. To, et al. (1994), however, found the Japanese equity market to be influential on the Asian emerging markets.

With regards to the existence of leads and lags among markets, the overwhelming evidence is that the United States leads other markets, with the exception of such markets as Korea, Taiwan and Thailand (see, for instance, Khoury, et al., 1987; Eun and Shim, 1989; Fischer and Palasvirta, 1990). There are, however, some studies that reported no lead/lag relationships among markets (e.g., Granger and Morgenstern, 1970; Hillard, 1979). It is interesting to note that some studies also reported that smaller markets do influence the US markets. For instance, in a study of the interaction among national equity markets, Huyghebaert and Wang (2010) find that Singapore and Hong Kong Granger-cause the US in their study of equity markets.

On the issue of transmission of shocks between markets, the results of previous other studies have also been mixed with some reporting that the transmission process is efficient, i.e., occurring within a period of one to two days (see, Schollhammer and Sand, 1987; Khoury, et al., 1987) while other studies (e.g. Ng, et al., 1991) reported the process to be inefficient.

Some studies point to the existence of a linkage between certain groups of equity markets based on some unifying or common factor, such as close regional, economic, and geographical relationships. To, et al. (1994) found the following clusters: Japan and Asian emerging markets, and the UK and African emerging markets. Hillard (1979) discovered a close association among intra-continental markets during the oil crisis of 1973 while Jorion (1989) reported a high degree of linkage among European continental markets. An AngloSaxon cluster was also reported by Jorion (1989).

In summary, this paper therefore provides knowledge on the extent of integration and linkages among SRI markets worldwide. In doing so, the study extends the literatures on SRI and financial market integration. It also provides practical contributions to investors and policymakers as knowledge of the linkages among SRI markets would be highly important to them.

The remaining parts of this paper are organised as follows. The next section provides a further background of SRI. Section three presents a brief discussion of the data and methodologies used in the study. Section four presents the empirical results followed by the conclusion in section five. 


\section{INSTITUTIONAL BACKGROUND}

SRI is a broad term to describe an investment process, which takes environmental, social, ethical, and/or governance considerations into account. This process stands in addition to or is incorporated into the usual fundamental investment selection and management process. SRI has a long history dating back to the 18th century that begins with religious groups such as the Quakers and Methodists who initiated this type of investing. Since the late 1960's the focus and support for SRI has expanded, the expansion was driven by a number of factors such as the rise of the civil rights movement, environmentalism and concerns about globalisation (Kinder, et al., 1993). In recent years, supra-national bodies have been formed such as the Global Reporting Initiative, United Nations Environment Programme, and United Nations Principles for Responsible Investment, among others. This development, jointly with the progress of corporate initiatives towards environmental and social impact information disclosure eventually created fertile ground for the SRI markets (SIF-J, 2007).

SRI differs from conventional investments in several ways. First, SRI is targeted at companies that adhere to the environmental, social and corporate governance (ESG) requirements or screens as determined by these funds. There are three dominant SRI screening practices employed today, i.e. negative, positive, and the best of sector screens. Each of these has been described by Lee (2006) as follows:

1. Negative or exclusionary SRI screens typically seek to exclude companies based on a set of social and environmental criteria. They commonly screen out so-called 'sin stocks' such as companies dealing with alcohol, tobacco, weapons, gambling, uranium and pornography. This is the most common method of screenings that is relatively easy to implement and administer.

2. Positive screens seek to promote and select companies based on their demonstrated ability and commitment to social and environmental issues. This screening is much broader with respect to the range of companies, industries and countries that can be included in an investors SRI portfolio. Also, it allows fund managers and investors an increased selection of securities across a range of industries and countries that otherwise would not have been available if negative screenings were employed. As 
such, positive screens increase one's investment opportunity set and thus returns potential whilst allowing for greater levels of adequate diversification. This may include water and waste management, renewable energy and energy efficiency, sustainable agriculture, mass transport, sustainable property, education, aged care and health care.

3. Another type of inclusive screen, like the positive SRI screen, is the best of sector approach. This process involves identifying leaders that are taking their industry toward a sustainable future. The approach is based on the premise that companies with strong sustainability credentials are generally better managed companies, and therefore better investments. This strategy is also a more inclusive SRI screen in that it favours those companies with the best social and environmental performance within each economic sector. Best of sector screening requires a very detailed country, industry and company analysis to determine which firms lead their respective industries with regard to social, environmental and economic performance criteria.

The effect of these ESG screens on the performance of portfolios is one that is debated within the investment management literature. On one hand, it is suggested that these additional screens have positive impact on investors in terms of additional (Tippet, 2001) and higher returns. Investors in SRI are thought to derive non-financial utility that correspond to their moral preferences. These screens are also considered to represent an active selection strategy of firms with characteristics that are believed to yield superior performance (Bollen, 2007). The incorporation by these firms of ESG issues are thought to lead to lower cost of capital arising from the minimisation or avoidance of such risks as environmental risk and reputation risks. It is also claimed that these firms are better managed, and that they take more consideration of the welfare of their customers, which then lead to increased revenues and higher returns (Renneboog, et al., 2006). On the other hand, it is argued that the exclusion of companies that fail these criteria may reduce the diversification possibilities and negatively influence the performance of the SRI funds in comparison to conventional funds. Further, it is also contended that the use of the additional screens can result in additional costs which can result in lower net returns (Mill, 2006 and Jones, et al., 2007). The bulk of the evidence on the performance of SRI seems to show that there is no significant difference in performance between SRI and conventional investment (see, Renneboog, et al., 2008). 
From the point of view of investment management, it appears therefore that the main concern with SRI relates to its more limited diversification which can negatively affect returns. As mentioned earlier, given the very substantial growth of SRI markets over the last three decades which have now resulted in the existence of significant SRI markets worldwide, there is an opportunity to alleviate this problem through international diversification. The pursuit of this strategy necessitates knowledge of the linkages between different SRI markets worldwide as the size of the benefits from international diversification is dependent on the extent of linkages between markets. This paper, as stated earlier, addresses this issue. It examines the price integration and linkages among major SRI markets worldwide represented by Australia, Canada, Japan, US and UK over the period 1994 to 2010.

\section{EMPIRICAL SPECIFICATIONS AND DATA}

Integration entails the equality of price or risk-adjusted returns ${ }^{2}$. It also implies co-movements in prices. Investigating integration based on price or risk-adjusted returns requires the use of asset pricing models. The use of asset pricing models, however, creates difficulty in examining financial integration. For example, if no integration is found, this can mean either that there is indeed no integration at all or that the asset-pricing model used is not valid. To avoid this problem, this paper examines integration based on co-movement of prices. The higher the co-movement of prices and the faster the response of prices in one market to the movements of prices in the other market, the greater the degree of integration. Thus, in this paper, we examine the integration between SRI markets through an analysis of the extent, duration and speed of interaction among the SRI markets.

In order to gauge the degree of price co-movement between SRI markets, we first conduct a vector autoregression (VAR) analysis to identify the markets which have significant price comovements. Then, we perform the variance decomposition (VDC) analysis among the markets, which have been identified to be significantly related to determine the extent of interaction between these markets and to identify which markets are the most and least influential. Finally, in order to find out the duration and speed of interaction between the

\footnotetext{
${ }^{2}$ As argued by Kenen (1976): “... integration refers to the degree to which participants in any market are enabled and obliged to take notice of events occurring in other markets. They are enabled to do so when information about those events is supplied into the decision making processes of recipients. They are obliged to do so when it is supplied in ways that invite them to use it in order to achieve their own objectives...” This definition therefore, implies information spill-over.
} 
markets, we undertake an impulse response analysis. We provide in the ensuing paragraphs further details on the VAR, VDC and impulse response analyses. Since each of these techniques is now well-known in the literature, we only provide a brief discussion of each. For readers who are interested in more details, we refer them to the relevant materials which we cite.

We perform a Vector Autoregression (VAR) analysis (Sims, 1980) in an unrestricted reduced form equation system. We estimate a five-market VAR systems represented by Equation 1 below.

$$
R_{t}=\alpha+\sum_{k=1}^{L} \beta_{k} R_{t-k}+\varepsilon_{t}
$$

where $R_{t}$ is a $5 \times 1$ column vector of weekly SRI market returns, $\alpha$ and $\beta_{k}$ are respectively, 5 $\times 1$ and $5 \times 5$ matrices of coefficients, $L$ is the lag length and $\varepsilon_{t}$ is a $5 \times 1$ column vector of serially uncorrelated error terms, The $i, j^{\text {th }}$ component of $\beta_{k}$ measure the direct effect on the $i^{\text {th }}$ market of a change in the return to the $j^{\text {th }}$ market in the $k$ periods. In effect, the $i^{\text {th }}$ component of $\varepsilon_{t}$ is the innovation of the $i^{\text {th }}$ market which cannot be predicted from past returns of other markets in the system.

More generally, a $\operatorname{VAR}(\mathrm{p})$ may be written as $y_{t}=\Phi_{i} x_{t}^{\prime}+u_{t}$ where $t=1,2, \cdots, n ; y_{t}$ is a $\mathrm{m} \times 1$ vector, $x_{t}=\left(1, x_{t}=\left(y_{t}, y_{t-1}, \cdots, y_{t-p}\right)\right)$ and $\Phi_{i}, i=0,1,2, \cdots, p$; and $u_{t}$ is white noise with covariance matrix $\sum$. The variables are stationary and the regressors are not perfectly collinear. Under certain conditions (Bruggemann, et al., 2008), the MA( $\infty)$ version of the VAR may be written as $y_{t}=\sum_{i=0}^{\infty} B_{i} u_{t-i}$ where $B_{j}=B_{j-1} \Phi_{1}+B_{j-2} \Phi_{2}+\cdots+B_{j-p} \Phi_{p}$ where $j=1,2, \cdots$, with $B_{0}=I_{m}$; and for $j<0, B_{j}=0$. There are in fact two ways of investigating variance decomposition and since the first orthogonized method is well known it is not reviewed. The second generalised version involves forecast at $t+N$ conditional on data available at $\mathrm{t}-1$ and the error in predicting $y_{t+N}$ is given by $\varepsilon_{t}(N)=\sum_{i=0}^{N} B_{i} u_{t+N-i}$ where $\varepsilon_{t}(N)$ is an m by 1 matrix and the total forecast error covariance is $\operatorname{Cov}\left[\varepsilon_{t}(N)\right]=\sum_{i=0}^{N} B_{i} \Sigma B_{i}^{\prime}$. It is important now to 
consider the forecast error covariance matrix of predicting $\mathrm{y}_{\mathrm{t}+\mathrm{N}}$ conditional on information at $\mathrm{t}-1$ and given values of the shocks to the $j^{\text {th }}$ equation $\left(\mu_{i j t}, \mu_{j t+1}, \ldots, \mu_{j t+N}\right)$

Given $\varepsilon_{t}^{(j)}(N)=\sum_{i=0}^{N} B_{i}\left(u_{t+N-i}-E\left[\mu_{t+N-i} \mid \mu_{j t+N-i}\right]\right)$ and assuming $\mu_{j} \approx N(0, \Sigma)$, the expectation is given as $E\left[\mu_{j} \mid \mu_{j t}=\delta_{j i}\right]=\left(\sigma_{1 j}, \sigma_{2 j}, \cdots, \sigma_{N j}\right)^{\prime} \sigma_{j j}{ }^{-1} \delta_{j}$ where $\delta=\sigma_{j j}^{-\frac{1}{2}}$ is for one standard deviation shock. $E\left[\mu_{t+N-i} \mid \mu_{j t+N-i}\right]=\left(\sigma_{j j}^{-1} \sum e_{j}\right) \mu_{j t+N-i}$ for $i=1, \cdots, N$ while $j=1, \cdots, m$; with $e_{j}$ being $\mathrm{m} \times 1$ and all element being zero except $j^{\text {th }}$ that is one.

Substitution into earlier equation and taking expectation gives:

$$
\operatorname{Cov}\left[\varepsilon^{(j)}{ }_{t}(N)\right]=\sum_{i=0}^{N} B_{i} \Sigma B_{i}^{\prime}-\sigma_{j j}^{-1}\left[\sum_{i=0}^{N} B_{i} \Sigma e_{i} e_{i}^{\prime} \Sigma B_{i}^{\prime}\right]
$$

Conditioning future shocks to $j^{\text {th }}$ equation allows to decreasing variance in an $N$ step forecast, and the second term in the covariance equations gives the lowering of the variance over forecast steps. Finally, scaling the $k^{\text {th }}$ term in the sequence with $j^{\text {th }}$ variance provides the formulae for generalised forecast error variance decomposition as used in this study (Ewing, 2001):

$$
\Gamma_{k j N}=\frac{\sigma_{j j}^{-1} \sum_{i=0}^{N}\left(e_{k}^{\prime} B_{i} \Sigma e_{j}\right)^{2}}{\sum_{i=0}^{N}\left[e_{j} B_{i} \Sigma B_{i}^{\prime} e_{j}\right]}
$$

The generalised formula is invariant to the order of variables appearing in the VAR, and is equal to the orthogonal version when the covariance matrix is diagonal. The generalised formula provides results that are not conditioned on ordering of variables.

We conduct a number of diagnostic tests are conducted before performing the VAR analysis. In order to determine the stationarity of the data, unit root tests based on the Augmented Dickey Fuller and Phillips Peron tests are performed first. The optimal lags to be used in the model are also tested first based on the Schwartz Information (SIC) criterion. As these tests are already well-known in the literature, discussions of these tests are no longer provided. 
This study investigates international integration among socially responsible investment (SRI) markets focusing on the markets of Australia, Canada, Japan, the UK and the US. These markets are the world's leading and fast growing SRI markets (DJSI, 2007; Gardner, 2007). Data from Dow Jones Sustainable Index (DJSI) are collected via DataStream. The DJSI derives its investment universe from the DJTM World with both indices employing the same methodology for calculating, reviewing and publishing their indices. The full integration of the two indices enables a direct comparison of each index's characteristics, whilst allowing for a direct comparison of their relative risks and performance.

The DJSI employs the best of sector approach in screening companies. Its primary source of information comes from a company questionnaire with over 70 multiple-choice questions focusing on the economic, environmental and social dimensions with equal weighting in each of those dimensions. A senior member of the management from each DJSI rated company is then required to sign off on each questionnaire as a means of ensuring its accountability and accuracy. The remainder of the ratings information is subsequently sourced from either the specific request for company documentation or by direct dialogue between the analyst and company and finally through media and internet research. A major strength of DJSI is that it is one of the only SRI indices that is fully and regularly audited and verified by independent auditors (Beloe, et al., 2004).

The sample period for the study is from January 1994 to May 2010. We allow for structural breaks in the data pertaining to the September 11 and global financial crises. Hence, the sample period is divided into three sub-periods: (1) pre-September 11 sub-period, from January 3, 1994 to September 6, 2001; (2) post-September 11 sub-period, from September 18, 2001 to July 31, 2008; and (c) global financial crisis sub-period, from August 1, 2008 to May 31, 2010. This study utilises daily data. All SRI indices are expressed in US dollars, as stated earlier, and the data used are in the form of returns on the price indices calculated by the formula: $R_{t}=\ln \left(\right.$ price $_{t} /$ price $\left._{t-1}\right) \times 100^{3}$.

Figure 1 illustrates the movement of the SRI indices. The Canadian SRI index peaked in 2000 and fell greatly in 2001, which could be explained by the September 11, 2001 crisis. Similar

\footnotetext{
${ }^{3}$ The continuous return formula is used as it is well-known to provide more accurate measure of return compared to the discrete formula (Brailsford, et al., 2004, pp. 9).
} 
behaviour seems to apply to the US and Japan markets. On the other hand, the Australian and UK markets exhibited sustained growth over the years.

\section{[Insert Figure 1 Here]}

\section{EMPIRICAL RESULTS}

\subsection{DATA PRELIMINARIES}

Table 1 shows that the mean returns were highest during the sub-period 2 (post-September 11) for Australia and Japan whereas for the other SRI markets - Canada, UK and US, it was during sub-period 1 (pre-September 11). All markets experienced the lowest average returns during the GFC period. However, it is noticeable that Australia and Canada continued to have positive returns while the other markets had negative returns. Thus, it appears that Australia and Canada were the only SRI markets that weathered the GFC and were therefore the best performers during this sub-period.

The table also points to a presence of non-normalities in the distributions of the variables. In general, the skewness of the return series indicates distributions around the means, but with fat tails in several cases. The resulting Jacque-Bera statistics signify that the normality distribution assumption is not fulfilled. However, the Augmented Dickey-Fuller (ADF) and Phillips-Perron (PP) tests consistently reject the null hypothesis (i.e. $\mathrm{H}_{0}: \gamma=0$ ) that the series has a unit root and thereby confirm that all returns series are stationary.

\section{[Insert Table 1 Here]}

\subsection{PRELIMINARY ANALYSIS BASED ON CORRELATIONS}

We conduct a preliminary analysis of the extent of integration between the SRI markets based on correlations. As can be seen in Table 2, the overall correlations between the SRI markets increased over the years from 0.16 in sub-period 1 to 0.27 in sub-period 2 and to 0.29 in subperiod. However, these correlations remain relatively low - below 0.30 . This indicates that there is a low level of integration among SRI markets although this linkage is increasing over the years. This therefore implies that there is a significant scope for international 
diversification across SRI markets worldwide. This also seems to confirm the suspicion that the globalisation of SRI markets is starting to increase the linkages among SRI markets.

[Insert Table 2 Here]

Table 2 further shows that Japan has the lowest correlation with other markets. During the first sub-period, the US was the market most linked to other markets (highest correlation) but in the second sub-period, the other markets, except Japan, overtook it. The UK and Canada are the markets which are most correlated with other markets. The highest correlations occurred between the following markets: US vs. Canada, UK vs. Canada, Australia vs. Japan, Australia vs. UK and US vs. UK while the lowest correlation was between Japan vs. UK.

The results of the correlation analysis therefore indicate that the SRI markets are becoming more linked or integrated over the years. We put this observation in the context of the relationship between stock markets since SRI markets are a part of stock markets. In this regard, we present the correlations between the stock markets of the Australia, Canada, Japan, UK, and US in Table 3. It can be clearly seen from this Table that the correlations between stock markets increased over the years. However, the increase in correlations between SRI markets (shown in Table 2) is much higher than the increase in correlations between national equity markets. Hence, the increasing linkages between SRI markets could not be solely due to the increasing integration between stock markets and therefore is worthy of a separate investigation. As discussed previously, SRI as a form of investment significantly differs from conventional investment and therefore needs to be examined in separately.

\section{[Insert Table 3 Here]}

In the light of these circumstances, we therefore conduct a further analysis of the relationship among the SRI markets based on methodologies that are more robust than correlation. It is already well-known in the literature that correlations suffer from a number of weaknesses including the assumption of linearity. We apply VAR, VDC and impulse response analyses as these are known to overcome problems of misspecification and also allow for a simultaneous multi-variable analysis. 
Before estimating the VAR, we first determine the optimum lag to be used. Test results for the optimum lags are presented in Table 4 . The results show that a lag of 1 was significant in both periods. Hence, a VAR with lag 1 is going to be estimated.

[Insert Table 4 Here]

\subsection{SigNificANT MARKET LiNKAGES}

We first perform the VAR analysis to determine which markets are significantly linked. In performing this analysis, we control for the effect of the size of each market. The VAR is estimated based on the weighted returns of each market where the weight for each market is the proportion of the capitalisation of each market in relation to the total capitalisation of the five markets derived from DJSI. The results from the VAR analysis are presented in Table 4. It can be seen from the table that all markets have a significant coefficient - either as a market influencing another market or as a market that is being influenced. Thus, there is significant interdependence among all markets which supports the findings from the correlation analysis. We therefore investigate the degree and manner of interaction among the markets that are significantly lined in the next two sections based on the VDC and impulse response analysis.

\section{[Insert Table 5 Here]}

\subsection{DEGREE OF INTERDEPENDENCE BETWEEN SRI MARKETS}

Since all markets are significantly linked, we therefore estimate the magnitude of the linkage of each market. This is done through the VDC. The results show the percentage of the forecast variance of each market, listed in the different rows, which are accounted for by each market listed in the different columns of the table. The number in the diagonal line represents the percentage of the forecast variance that is due to itself while the rest of the numbers in each row would represent the effect of other markets, on a particular market, which are totalled in the last column. The total effect of each market on other markets is given by each number shown in the row titled "effect on other markets". Thus, the outputs of the VDC indicate the impact of each market on other markets, as well as the extent by which each market is influenced by other markets. From the results of the VDC, we can identify which 
markets are most (less) influential and more (less) open. We can also infer from the VDC results the extent of openness of all the markets.

\section{[Insert Table 6 Here]}

The results of the VDC analysis, which is reported in Table 6, also confirm the results from the correlation analysis - that is, that the SRI markets have become more integrated over the years. As can be seen in Table 6, in the last column, the SRI markets have become more affected by other markets (from 47.3 in sub-period 1 to 122.3 in sub-period 2 to 239.8 in subperiod 3). During the pre-crisis sub-period (sub-period 1), it was only the US that was most open with $25.7 \%$ of its forecast variance being driven by other markets. This is reflection of the early development of the SRI market and its globalisation. However, in the second subperiod, in addition to the US, the UK and Japanese markets also became highly open markets. For each of these three markets, around $30 \%$ of their forecast variances were due to other markets. Finally, in the third sub-period, these three markets continued to be the most open markets and in fact, became more open with $66.2 \%$ of the UK's, $61.3 \%$ of the US's and $48.7 \%$ of Japan's forecast variance being accounted for by other markets. The GFC therefore resulted in these SRI markets being more affected by other markets. Again, this could be due to US, UK and Japanese companies being cross-listed in foreign markets which make them vulnerable to the conditions of those foreign markets, such as Canada and Australia.

The market with the most effect on other markets is Canada that accounted, on the average, for a total of $63.1 \%$ of the forecast variance of all other markets. The second most influential market is Australia as this accounted for $41.4 \%$ of the forecast variance of all other markets. Japan, on the other hand, had the lowest overall effect on other markets, accounting for less than $1 \%$ of the forecast variance of the other markets. The Canadian market mainly drives the US and UK markets while the Australian market influences greatly the UK, Canadian and Japanese markets. Again, the Canadian SRI market, while not as large as the US, is also relatively significant and has grown substantially over the years. The Australian market, while much smaller than that of Canada, has been the fastest growing market over the years. Again, most US companies that are considered to be sustainable are also heavily involved in the Canadian and Australian market and therefore developments in these two markets will also affect the US market. The study by Huyghebaert and Wang (2010) in relation to the integration of stock markets has also confirmed this phenomenon. They found that Hong Kong and Singapore drive the US market. 
In summary, the forecast variance decomposition analyses results indicate that the markets became more interdependent over the years. Canada and Australia are the most influential SRI markets while Japan is the least influential. Further, the US is the most open and interdependent market while Canada is the least.

\subsection{DURATION AND SPEED OF INTERACTION BETWEEN SRI MARKETS}

In the last part of our examination of the integration between SRI markets worldwide, we investigate the manner of interaction between the markets which are significantly linked. We analyse the speed and duration of the co-movement between the markets. The shorter (longer) and the faster (slower) the interaction is, the more (less) integrated the markets are. As discussed in the methodology section of the paper, this is done based on the impulse response analysis within the context of the VAR system. Impulse responses provide evidence on how much and how quick the movement of one market is transmitted to the others.

The impulse responses of each SRI market to the price movements from other markets are plotted in Figure 2. An inspection of Figure 2 reveals that all responses were immediate in all the three sub-periods - that is, each market immediately responded to news from other markets during the first day. The responses are completed within a period of 2 to 3 days - that is, each market is able to finish its reaction to other markets within this time period. In the international finance literature, this duration of response is considered to be efficient. We therefore interpret as further evidence that the SRI markets are quite significantly linked or integrated.

The sensitivity to external shocks varies significantly among the markets. The US and the UK are the most responsive markets while Australia and Canada are the least. Thus, the US and the UK are the most while Australia and Canada are the least open markets. The UK and the US have also become more responsive over the years particularly during the GFC sub-period. Again, this implies that these two markets are becoming more integrated with other markets. As also shown in Figure 2, the US and the UK have even become more sensitive to other markets during the GFC sub-period - meaning, they have been more affected by events in other markets during this sub-period. Once again, this could be because of the heavy presence of their companies overseas. 
[Insert Figure 2 Here]

In summary, therefore, the impulse response analysis results also point to an increasing integration among the SRI markets over the years.

\section{CONCLUSION}

This paper investigates the international integration of SRI markets through an examination of the extent, speed and duration of price interaction between the markets of Australia, Canada, Japan, UK and US using daily DJSI data covering the period 1994-2007. The period is divided into three sub-periods to allow for the structural break arising from the September 11 and Global Financial crises. The study employs variance decomposition and impulse response analysis based on the VAR context. A preliminary analysis is also conducted based on correlations.

The results show that all SRI markets significantly affect each other. The markets respond to each other quite speedily and within a short period of time. Furthermore, the linkage between the SRI markets increased over the years, particularly during the GFC period. These results indicate that the markets are becoming more significantly integrated over the years; however, this integration is still at a low level. This implies, therefore, that there is still very significant scope for SRI investors to diversify internationally across SRI markets.

In terms of specific markets, the study found that the US and the UK are the most significantly open and interlinked markets which reflect the high globalisation of these markets. These markets are affected heavily by movements in prices in the other SRI markets. This had become particularly so during the GFC period. On the other hand, Australia and Canada seems to be more driven by events in their own markets rather than by those in other markets. Thus, from the point of view of portfolio diversification, it appears that Australia and Canada can provide better benefits as compared to the US and the UK, as the former two markets enjoy lower correlations with other markets while the latter have higher correlations.

In conclusion, the results of the study indicate that SRI markets are interdependent and integrated and become more so over the years. However, since the level of integration among the markets is still relatively low, SRI investors and trustees may be heartened that there are 
still benefits to be gained by internationally diversifying across SRI markets worldwide. This would therefore allow them to alleviate to a certain extent the limitation on diversification that they suffer in their involvement in SRI. These results should also be of concern to financial regulators. Since SRI markets have been found to be significantly integrated, there is the risk of contagion among markets. This would therefore require a coordination of policies across SRI markets worldwide if contagion risk is to be contained or eliminated. 


\section{REFERENCES}

Adler, M. and B. Dumas, (1983), "International Portfolio Choice and Corporation Finance: A Synthesis”, Journal of Finance, 38, 925-984

Agmon, T., (1972), "The Relations among Equity Markets: A Study of Share Price CoMovements in the United States, United Kingdom, Germany and Japan”, Journal of Finance, 4, 839-1317

Angel, J. and P. Rivoli, (1997) "Does Ethical Investing Impose a Cost upon the Firm? A Theoretical Examination”, Journal of Investing, 6, 57-61

Bauer, R., K. Koedik, and R. Otten, (2005) "International Evidence on Ethical Mutual Funds Performance and Investment Style”, Journal of Banking and Finance, 29, 1751-1767

Bauer, R., J. Derwall, and R. Otten, (2007) “The Ethical Mutual Fund Performance Debate: New Evidence from Canada”, Journal of Business Ethics, 70, 111-124

Becker, K., J. Finnerty, and M. Gupta (1990), “The Intertemporal Relation between the US and Japanese Stock Markets”, Journal of Finance, 45, 1297-306

Beloe, S., J. Scherer, and I. Knoepfel, (2004) "Values for Money: Reviewing the Quality of SRI Research", http://www.sustainability.com/insight/sri-article.asp?id=136 (last accessed June 20, 2010)

Bollen, N.P., (2007), “Mutual Fund Attributes and Investor Behavior”, Journal of Financial and Quantitative Analysis, 42, 683-708

Brailsford, T., R. Heaney, and C. Bilson, (2004), "Investments: Concepts and Applications", 2nd ed, Thomson, South Melbourne

Bruggemann, R., W. Hardle, J. Mungo, and C. Trenkler, (2008), "VAR Modelling For Dynamic Loadings Driving Volatility Strings", Journal of Financial Econometrics, 2008, 121

Canadian Social Investment Organization (2006) "The Canadian Association for Socially Responsible Investment” www.socialinvesment.ca [last accessed on July 7, 2010]

Chi, J., Le, K., and Young, M. (2006). “Financial Integration in East Asian Equity Markets”, Pacific Economic Review, 11(4), 513-526.

Click, R.W. and Plummer, M.G. (2005). "Stock Market Integration in ASEAN after the Asian Financial Crisis”, Journal of Asian Economics, 16, 5-28.

DiBartolomeo, D. and L. Kurtz., (1999) “Managing Risk Exposures of Socially Screened Accounts”, Northfield Working Paper, 1999

DJSI, (2007), “World's Leading Countries in Socially Responsible Investments” http://www.sustainability-indices.com/htmle/data/components_djsiworld.html (last accessed June 11, 2010)

Dwyer, G., and R. Hafer, (1988), “Are National Stock Markets Linked?”, Review, Federal Reserve Bank of St. Louis, 70, 3-14 
Edmans, A., (2007), “Does the Stock Market Fully Value Intangibles? Employee Satisfaction and Equity Prices”, MIT Working Paper, 2007Espitia and Santamaria, 1994

Espitia, M. and R. Santamaria (1994). "International Diversification Among the Capital Markets of the EEC”, Applied Financial Economics, 4, 1, pp. 1-10.

Eun, C. S., and S. Shim, (1989), "International Transmission of Stock Market Movements”, Journal of Financial and Quantitative Analysis, 24, 241-256

European Social Investment Forum, (2006), “European SRI Study 2006” http://www.eurosif.org/content/download/580/3548/version/1/file/Eurosif_SRIStudy_2006_c omplete.pdf (last accessed June 18, 2010)

Ewing, B. T. (2001), “Monetary policy and Stock returns”, Bulletin of Economic Research, 53, 73-79

Fischer, K., and A. Palasvirta (1990), "High Road to a Global Marketplace: The International Transmission of Stock Market Fluctuations”, Financial Review, 25, 371-94

Gardner, G., (2007), "Socially Responsible Investments Grows Rapidly" http://www.worldwatch.org/node/5481 (last accessed June 21, 2010)

Goodhart, C., (1988), “The International Transmission of Asset Price Volatility”, Financial Market Volatility, Kansas City, MO: Federal Reserve Bank of Kansas City, 79-120

Granger, C.W.J., and O. Morgenstern, (1970), Predictability of Stock Market Prices, Lexington, MA: Heath Lexington Books

Gregory, A., J. Matatko, and R. Luther, (1997) "Ethical Unit Trust Financial Performance: Small Company Effects and Fund Size Effects”, Journal of Business Finance and Accounting, 24, 705-725

Grubel, H.G., (1968), "Internationally Diversified Portfolios: Welfare Gains and Capital Flows”, American Economic Review, 58, 1299-1314

Guenster, N., J. Derwall, R. Bauer, and K. Koedijk, (2005), "The Economic Value of Corporate Eco-Efficiency”, Working Paper, Erasmus University, July 25, 2005

Guerard, J., (1997), “Is There a Cost to Being Socially Responsible in Investing?” Journal of Investing, summer, 6, 11-18

Hamao, Y., R.W. Masulis, and V. Ng, (1990), "Correlations in Price Changes and Volatility across International Stock Markets”, The Review of Financial Studies, 3, 281-307

Hamilton, S., H. Jo, and M. Statman, (1993), "Doing Well While Doing Good? The Investment Performance of Socially Responsible Mutual Funds”, Financial Analysts Journal, 49, 62-66

Hillard, J. E. (1979), “The Relationship between Equity Indices on World Exchanges”, Journal of Finance, 34, 103-114

Hong, H. and M. Kacperczyk, (2006), "The Price of Sin: The Effects on Social Norms on Markets”, Working Paper, Princeton University, April 2006 
Huyghebaert, N. and L. Wang, (2010), “The Co-Movement of Stock Markets in Asia: Did the 1997-1998 Asian Financial Crisis Really Strengthen Stock Market Integration?” China Economic Review, 21, 98-112

Ibbotson, R.C., R.C. Karr, and A.W. Robinson (1982), "International Equity and Bond Returns”, Financial Analysts Journal, 38, 61-83

Jaffe, J. and R. Westerfield (1985), "Patterns in Japanese Common Stock Returns: Day of the Week and Turn-of-the-Year Effects”, Journal of Financial and Quantitative Analysis, 20, 261-272

Jeon, B.N. and G.W. Von Furstenberg, (1990), "Growing International Co-movement in Stock Price Indexes”, Quarterly Review of Economics and Business, 30, 15-30

Jones, S., S. van der Laan, G. Frost and J. Loftus, (2006), “The Investment Performance of Socially Responsible Investment Funds in Australia”, Journal of Business Ethics, 80, 181-203

Jorion, P., (1989), “The Linkages between National Stock Markets”, in aliber, R.Z. (ed.), The Handbook of International Financial Management, Illinois: Dow Jones - Irwin

Jorion, P., and E. Schwartz (1986), "Integration vs. Segmentation in the Canadian Stock Market”, Journal of Finance, 41, 603-614

Kenen, P.B., (1976), “Capital Mobility and Financial Integration: A Survey”, Princeton Studies in International Finance, No. 39, Princeton University

Khoury, S.J., B. Dodin, and H. Takada, (1987), "Multiple Time Series Analysis of National Stock Markets and Their Structure: Some Implications, in Khoury, S.J. and A. Ghosh (eds.), Recent Developments in International Banking and Finance, D.C. Heath and Co.

Kinder, P., A.L. Domini, and S.D. Lydenberg, (1993), “Investing for Good: Making Money While Being Socially Responsible”, Harper Business, New York

Kreander, N., R.H. Gray, D.M. Power, and C.D. Sinclair, (2005), "Evaluating the Performance of Ethical and Non-ethical Funds: A Matched Pair Analysis", Journal of Business Finance and Accounting, 32, 1465-1493

Lee, I., (1992), “Stock Market Seasonality: Some Evidence from the Pacific-Basin Countries”, Journal of Business, Finance, and Accounting, 19, 199-210

Lee, D., (2006), “An Analysis of the Sustainability Investment Strategy Employing the Dow Jones World Sustainability Index”, PhD Thesis submitted on July 2006 in Monash University

Lee, C. and D. Ng, (2002) “Corruption and International Valuation: Does Virtue Pay?” Cornell University, Working Paper, November 2002

Levy, H., And Z. Lerman, (1988), “The Benefits of International Diversification in Bonds”, Financial Analysts’ Journal, 56-64

Luther, R.G., J. Matatko, and D.C. Corner, (1992), "The Investment Performance of UK 'Ethical' Unit Trusts”, Accounting Auditing \& Accountability Journal, 5, 57-70

Makridakis, S.G., and S.C. Wheelwright, (1974), "An Analysis of the Interrelationships among World Stock Exchanges”, Journal of Business Finance \& Accounting, 1, 195-215 
Maldonado, R., and A. Saunders, (1981), "International Portfolio Diversification and the Inter-temporal Stability of International Stock Market Relationships, 1957-1978”, Financial Management, 10, 54-63

Mill, G., (2006), “The Financial Performance of Socially Responsible Investment Over Time and a Possible Link with Corporate Social Responsibility”, Journal of Business Ethics, 63, $131-148$

Ng, V., R.P. Chang, and R.W. Chou, (1991), “An Examination of the Behaviour of Pacific Basin Stock Market Volatility”, in Rhee, S.G. and R.P. Chang (eds.), Pacific Basin Capital Markets Research, 2, Holland: Elsevier Science Publishers, 245-260

Orlitzky, M., F.L. Schmidt, and S.L. Rynes, (2003), “Corporate Social and Financial Performance: A Meta-Analysis”, Organization Studies, 24, 2003

Panopoulou, E., \& Pantelidis, T., (2009), "Integration at a Cost: Evidence from Volatility Impulse Response Functions”, Applied Financial Economics, 19(11), 917

Panton, D.B., V.P. Lessig, and O.M. Joy (1976), "Co-movement of International Equity Markets: A Taxonomic Approach”, Journal of Financial and Quantitative Analysis, 11, 41532

Philippatos, G.C., A. Christofi, and P. Christofi, (1983), "The Intertemporal Stability of International Stock Market Relationships: Another View”, Financial Management, 12, 63-69

Renneboog, L, J. Horst, and C. Zhang, (2006) “Is Ethical Money Financially Smart?” Finance Working Paper No. 117/2006. European Corporate Governance Institute

Renneboog, L., J. Horst, and C. Zhang, (2008), "Socially responsible investments: institutional aspects, performance, and investor behaviour”, Journal of Banking and Finance, 32, 1723-1742

Responsible Investment Association Australasia, (2007) "Responsible Investment 2007" http://www.responsibleinvestment.org/files/78RUBP9VVA/RIAA\%20Benchmark\%20Report \%202007\%20FINAL.pdf (last accessed June 18, 2010)

Ripley, D., (1973), “Systematic Elements in the Linkage of National Stock Market Indices”, Review of Economics and Statistics, 55, 356-361

Roca, E.D., (1999), "Short-term and Long-term Price Linkages between the Equity Markets of Australia and its Major Trading Partners”, Applied Financial Economics, 9, 501-511

Roll, R. (1989a), “The International Crash of October 1987”, in Kamphuis, R., R. Karmendi, and J. Watson (eds.), Black Monday and the Future of Financial Markets, Homewood, IL: Irwin, 35-70

Roll, R., (1989b), "Price Volatility, International Market Links, and Their Implications for Regulatory Policies”, Journal of Financial Services Research, 3, 211-246

Russo, M. and P. Fouts, (1997), “A Resource-Based Perspective on Corporate Environmental Performance and Profitability”, Academy of Management Journal, June 1997 
Schollhammer, H., and O.C. Sand, (1987), "Lead-Lag Relationships among National Equity Markets: An Empirical Investigation”, in Khoury, S.J. and A. Ghosh (Eds.). Recent Developments in International Banking and Finance, 1, Cambridge, MA: Lexington, 149-168

SIF-J, (2007), "Socially Responsible Investments in Japan" http://www.sifjapan.org/sri/sri.html (last accessed June 18, 2010)

Sims, C.A., (1980), “Macroeconomics and Reality”, Econometrica, 48, 1-48

Smith, K. L., J. Brocato, and J.E. Rogers, (1995), “An Analysis of World Capital Market Return/Risk Ratios: A Test of Global Financial Integration during the 1980-1991 Period”, Managerial Finance, 21, 13-31

Social Investment Forum: Japan, (2007) “2007 Review of Socially Responsible Investment Japan” http://www.sifjapan.org/document/sri2007_english.pdf (last accessed June 18, 2010)

Social Investment Forum: United States, (2007) "Report on Responsible Investing Trends in the U.S. 2007” http://www.socialinvest.org/pdf/SRI_Trends_ExecSummary_2007.pdf (last accessed June 18, 2010)

Statman, M., (2000), “Socially Responsible Mutual Funds”, Financial Analysts Journal, 56, 30-39

Tippet, J., (2001), "Performance of Australia's Ethical Funds”, Australian Economic Review 34, $170-178$

To, M.C., K.G. Assoe, and S. Pariente, (1994), “The Efficiency of Emerging Stock Markets and Their Relationships with the World's Major Stock Exchanges”, Montreal: CETAI University of Montreal

Wheatley, S., (1988), “Some Tests of International Equity Market Integration”, Journal of Financial Economics, 21, 177-212 
Table 1

Descriptive Statistics

\begin{tabular}{|c|c|c|c|c|c|}
\hline & Australia & Canada & Japan & UK & US \\
\hline \multicolumn{6}{|c|}{ Sub-Period 1(Pre-September 11): 1994-2001 } \\
\hline Mean & 0.0002 & 0.0021 & 0.0016 & 0.0092 & 0.0236 \\
\hline Std. Dev. & 0.0291 & 0.1075 & 0.2395 & 0.2814 & 0.6245 \\
\hline Skewness & 0.1789 & -0.8560 & 0.4350 & 0.0717 & -0.2760 \\
\hline Kurtosis & 4.6501 & 22.8278 & 8.8086 & 4.5057 & 7.7047 \\
\hline Jarque-Bera & $238.16 *$ & $33,088.59 *$ & $2,881.91 *$ & $191.13 *$ & $1,874.55 *$ \\
\hline $\mathrm{ADF}$ & $-40.3539 *$ & $-32.8912 *$ & $-44.5643 *$ & $-32.9433 *$ & $-44.7176 *$ \\
\hline PP & $-40.1960 *$ & $-41.5231 *$ & $-44.6646 *$ & $-44.2206 *$ & $-44.9520 *$ \\
\hline \multicolumn{6}{|c|}{ Sub-Period 2(Post September 11): 2001-2008 } \\
\hline Mean & 0.0026 & 0.0018 & 0.0025 & 0.0073 & 0.0042 \\
\hline Std. Dev. & 0.0655 & 0.0349 & 0.1449 & 0.4094 & 0.5311 \\
\hline Skewness & -0.3691 & -0.3572 & -0.1719 & -0.1648 & 0.1533 \\
\hline Kurtosis & 11.0685 & 6.3999 & 4.6505 & 6.1960 & 6.2697 \\
\hline Jarque-Bera & $4904.29 *$ & $901.71 *$ & $212.35 *$ & $771.20 *$ & $805.71 *$ \\
\hline $\mathrm{ADF}$ & $-42.2571 *$ & $-43.3613 *$ & $-45.2856 *$ & $-27.8499 *$ & $-44.7129 *$ \\
\hline PP & $-42.5812 *$ & $-43.3501 *$ & $-45.6956 *$ & $-47.6923 *$ & $-44.9451 *$ \\
\hline \multicolumn{6}{|c|}{ Sub-Period 3 (GFC): 2008-2010 } \\
\hline Mean & 0.0014 & 0.0013 & -0.0045 & -0.0242 & -0.0125 \\
\hline Std. Dev. & 0.2093 & 0.1247 & 0.2550 & 0.8895 & 0.8799 \\
\hline Skewness & -0.3759 & -0.3760 & 0.1181 & 0.0860 & -0.1290 \\
\hline Kurtosis & 4.4917 & 6.4028 & 6.6761 & 7.9078 & 7.1633 \\
\hline Jarque-Bera & $55.81 *$ & $242.89 *$ & $271.39 *$ & $482.33 *$ & $348.00 *$ \\
\hline $\mathrm{ADF}$ & $-21.7493 *$ & $-17.9353 *$ & $-24.5177 *$ & $-22.1302 *$ & $-24.8554 *$ \\
\hline PP & $-21.7493 *$ & $-21.6075 *$ & $-24.7040 *$ & $-22.3034 *$ & $-25.0261 *$ \\
\hline
\end{tabular}

Note: * indicates significance at 5\% 
Table 2

Correlation Analysis Between SRI Markets

\begin{tabular}{|c|c|c|c|c|c|c|}
\hline & Australia & Canada & Japan & UK & US & $\begin{array}{c}\text { All } \\
\text { Markets }\end{array}$ \\
\hline \multicolumn{7}{|c|}{ Sub-Period 1(Pre-September 11): 1994-2001 } \\
\hline Australia & 1 & & & & & 0.1189 \\
\hline Canada & $0.0890 * * *$ & 1 & & & & 0.1916 \\
\hline Japan & $0.1785 * * *$ & $0.0483 * *$ & 1 & & & 0.1010 \\
\hline UK & $0.1567 * * *$ & $0.1716 * * *$ & $0.1323 * * *$ & 1 & & 0.1827 \\
\hline US & $0.0511 * *$ & $0.4577 * * *$ & 0.0435 & $0.2707 * * *$ & 1 & 0.2051 \\
\hline $\begin{array}{l}\text { Average } \\
\text { Correlation }\end{array}$ & 0.1189 & 0.1916 & 0.1010 & 0.1827 & 0.2051 & 0.1599 \\
\hline \multicolumn{7}{|c|}{ Sub-Period 2 (Post September 11): 2001-2008 } \\
\hline Australia & 1 & & & & & 0.2746 \\
\hline Canada & $0.2628 * * *$ & 1 & & & & 0.3236 \\
\hline Japan & $0.4912 * * *$ & $0.1304 * * *$ & 1 & & & 0.2106 \\
\hline UK & $0.3161 * * *$ & $0.4683 * * *$ & $0.1732 * * *$ & 1 & & 0.3382 \\
\hline US & 0.0283 & $0.4331 * * *$ & $0.0478 * *$ & $0.3953 * * *$ & 1 & 0.2261 \\
\hline $\begin{array}{l}\text { Average } \\
\text { Correlation }\end{array}$ & 0.2746 & 0.3236 & 0.2106 & 0.3382 & 0.2261 & 0.2747 \\
\hline \multicolumn{7}{|c|}{ Sub-Period 3(GFC): 2008-2010 } \\
\hline Australia & 1 & & & & & 0.4927 \\
\hline Canada & $0.4747 * * *$ & 1 & & & & 0.5296 \\
\hline Japan & $0.6025 * * *$ & $0.2457 * * *$ & 1 & & & 0.2906 \\
\hline UK & $0.6344 * * *$ & $0.6919 * * *$ & $0.2825 * * *$ & 1 & & 0.5440 \\
\hline US & $0.2592 * * *$ & $0.7061 * * *$ & 0.0315 & $0.5670 * * *$ & 1 & 0.3910 \\
\hline $\begin{array}{l}\text { Average } \\
\text { Correlation }\end{array}$ & 0.4927 & 0.5296 & 0.2906 & 0.5440 & 0.3910 & 0.2947 \\
\hline $\begin{array}{l}\text { Overall } \\
\text { Average } \\
\text { Correlation }\end{array}$ & 0.2954 & 0.3483 & 0.2007 & 0.3550 & 0.2741 & 0.2947 \\
\hline
\end{tabular}

Note: $* * *$ and $* *$ indicates significance at $1 \%$ and $5 \%$ 
Table 3

Correlation Analysis Between National Equity Markets

\begin{tabular}{|c|c|c|c|c|c|c|}
\hline & Australia & Canada & Japan & UK & US & $\begin{array}{c}\text { All } \\
\text { Markets }\end{array}$ \\
\hline \multicolumn{7}{|c|}{ Sub-Period 1 (Pre-September 11): 1994-2001 } \\
\hline Australia & 1 & & & & & 0.3877 \\
\hline Canada & $0.2264 * * *$ & 1 & & & & 0.4751 \\
\hline Japan & $0.3187 * * *$ & $0.1172 * * *$ & 1 & & & 0.3441 \\
\hline UK & $0.3127 * * *$ & $0.3415^{* * *}$ & $0.2540 * * *$ & 1 & & 0.4428 \\
\hline US & $0.0808 * * *$ & $0.6906 * * *$ & 0.0305 & $0.3059 * * *$ & 1 & 0.4216 \\
\hline $\begin{array}{l}\text { Average } \\
\text { Correlation }\end{array}$ & 0.3877 & 0.4751 & 0.3441 & 0.4428 & 0.4216 & 0.4143 \\
\hline \multicolumn{7}{|c|}{ Sub-Period 2 (Post September 11): 2001-2008 } \\
\hline Australia & 1 & & & & & 0.4800 \\
\hline Canada & $0.3845 * * *$ & 1 & & & & 0.5446 \\
\hline Japan & $0.5080 * * *$ & $0.1941 * * *$ & 1 & & & 0.3915 \\
\hline UK & $0.4200 * * *$ & $0.5456 * * *$ & $0.2098 * * *$ & 1 & & 0.5153 \\
\hline US & $0.0875 * * *$ & $0.5986 * * *$ & 0.0453 & $0.4010 * * *$ & 1 & 0.4265 \\
\hline $\begin{array}{l}\text { Average } \\
\text { Correlation }\end{array}$ & 0.4800 & 0.5446 & 0.3915 & 0.5153 & 0.4265 & 0.4716 \\
\hline \multicolumn{7}{|c|}{ Sub-Period 3 (GFC): 2008-2010 } \\
\hline Australia & 1 & & & & & 0.6217 \\
\hline Canada & $0.5441 * * *$ & 1 & & & & 0.6549 \\
\hline Japan & $0.5864 * * *$ & $0.2483 * * *$ & 1 & & & 0.4192 \\
\hline UK & $0.7040 * * *$ & $0.7363 * * *$ & $0.2798 * * *$ & 1 & & 0.6579 \\
\hline US & $0.2741 * * *$ & $0.7455 * * *$ & -0.0185 & $0.5694 * * *$ & 1 & 0.5141 \\
\hline $\begin{array}{l}\text { Average } \\
\text { Correlation }\end{array}$ & 0.6217 & 0.6549 & 0.4192 & 0.6579 & 0.5141 & 0.5736 \\
\hline $\begin{array}{l}\text { Overall } \\
\text { Average } \\
\text { Correlation }\end{array}$ & 0.4965 & 0.5582 & 0.3849 & 0.5387 & 0.4540 & 0.4865 \\
\hline
\end{tabular}

Note: $* * *$ and $* *$ indicates significance at $1 \%$ and $5 \%$ 
Table 4

Optimum Lag Test Results

\begin{tabular}{lcccc}
\hline & \multicolumn{4}{c}{ Lags } \\
\cline { 2 - 5 } Periods & $\mathbf{0}$ & $\mathbf{1}$ & $\mathbf{2}$ & $\mathbf{3}$ \\
\hline $\begin{array}{l}\text { Sub-Period 1 (Pre- } \\
\text { September 11): 1994- }\end{array}$ & -4.0459 & $-4.1003 *$ & -4.0356 & -3.9626 \\
$\begin{array}{l}\text { 2001 } \\
\text { Sub-Period 2 (Post }\end{array}$ & & & \\
$\begin{array}{l}\text { September 11): 2001- } \\
\text { 2008 }\end{array}$ & -5.8451 & $-6.2732 *$ & -6.2077 & -6.1469 \\
$\begin{array}{l}\text { Sub-Period 3 (GFC): } \\
\text { 2008-2010 }\end{array}$ & 1.3116 & $0.4750 *$ & 0.5436 & 0.7517 \\
\hline Note* * indicates lowest Schwarz Information Criterion
\end{tabular}

Note: * indicates lowest Schwarz Information Criterion 


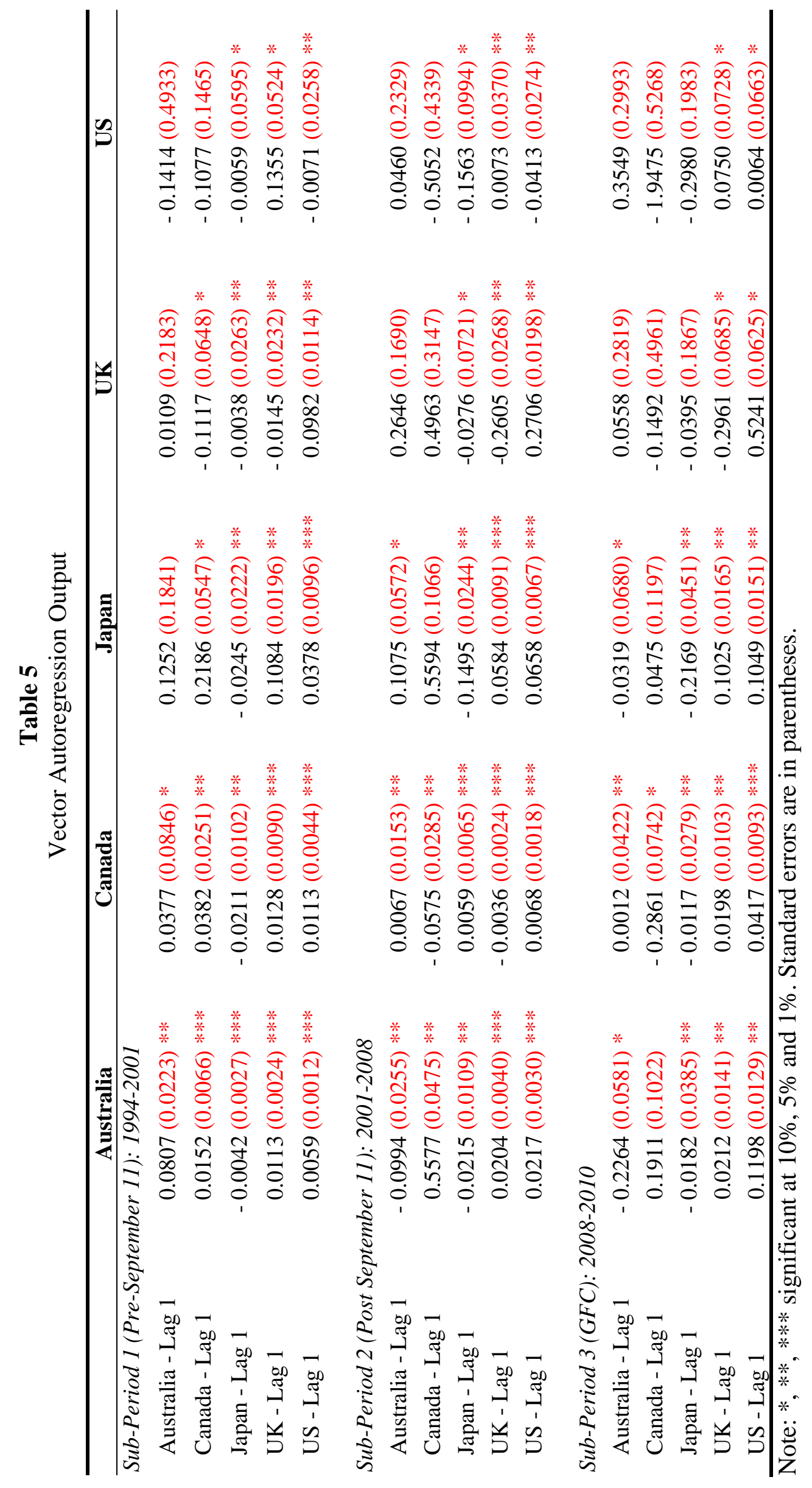


Table 6

Variance Decomposition Analysis Result

\begin{tabular}{|c|c|c|c|c|c|c|}
\hline \multirow[b]{2}{*}{$\begin{array}{l}\text { Dependent } \\
\text { variable }\end{array}$} & \multicolumn{6}{|c|}{ Independent variable } \\
\hline & Australia & Canada & Japan & UK & US & $\begin{array}{l}\text { Total effect } \\
\text { of other } \\
\text { markets }\end{array}$ \\
\hline \multicolumn{7}{|c|}{ Sub-Period 1 (Pre-September 11): 1994-2001 } \\
\hline Australia & 95.2306 & 1.6985 & 0.0426 & 1.7337 & 1.2947 & 4.7694 \\
\hline Canada & 0.4714 & 98.8376 & 0.1655 & 0.2048 & 0.3206 & 1.1624 \\
\hline Japan & 1.8028 & 2.6263 & 92.7391 & 2.0288 & 0.8030 & 7.2609 \\
\hline UK & 1.6502 & 2.5085 & 0.7664 & 91.5428 & 3.5321 & 8.4572 \\
\hline US & 0.2230 & 20.9124 & 0.0651 & 4.4753 & 74.3241 & 25.6759 \\
\hline $\begin{array}{l}\text { Total effect on } \\
\text { other markets }\end{array}$ & 4.1475 & 27.7457 & 1.0396 & 8.4426 & 5.9504 & 47.3339 \\
\hline \multicolumn{7}{|c|}{ Sub-Period 2 (Post September 11): 2001-2008 } \\
\hline Australia & 78.1845 & 16.8406 & 0.1076 & 2.4988 & 2.3685 & 21.81549 \\
\hline Canada & 8.8238 & 90.2922 & 0.0680 & 0.0166 & 0.7994 & 9.707832 \\
\hline Japan & 12.4483 & 8.6842 & 70.3244 & 4.2404 & 4.3028 & 29.67563 \\
\hline UK & 8.2364 & 15.1424 & 0.0301 & 67.0471 & 9.5440 & 32.95294 \\
\hline US & 0.4054 & 19.6337 & 0.3403 & 7.7734 & 71.8472 & 28.15281 \\
\hline $\begin{array}{l}\text { Total effect on } \\
\text { other markets }\end{array}$ & 29.9139 & 60.3009 & 0.5460 & 14.5292 & 17.0146 & 122.3047 \\
\hline \multicolumn{7}{|c|}{ Sub-Period 3 (GFC): 2008-2010 } \\
\hline Australia & 65.2389 & 22.3030 & 0.2566 & 2.3010 & 9.9006 & 34.76114 \\
\hline Canada & 23.2848 & 71.1114 & 0.1340 & 2.0819 & 3.3879 & 28.88856 \\
\hline Japan & 17.9468 & 16.8571 & 51.3441 & 8.0625 & 5.7896 & 48.65589 \\
\hline UK & 30.2052 & 24.3768 & 0.2590 & 33.8142 & 11.3449 & 66.18584 \\
\hline US & 18.5859 & 37.8321 & 0.6665 & 4.2438 & 38.6717 & 61.32832 \\
\hline $\begin{array}{l}\text { Total effect on } \\
\text { other markets }\end{array}$ & 90.0226 & 101.3690 & 1.3161 & 16.6892 & 30.4229 & 239.8198 \\
\hline $\begin{array}{l}\text { Overall Period } \\
\text { Average Effect } \\
\text { on Other } \\
\text { Markets }\end{array}$ & 41.3757 & 63.1377 & 0.9738 & 13.1765 & 17.7899 & 136.4536 \\
\hline
\end{tabular}




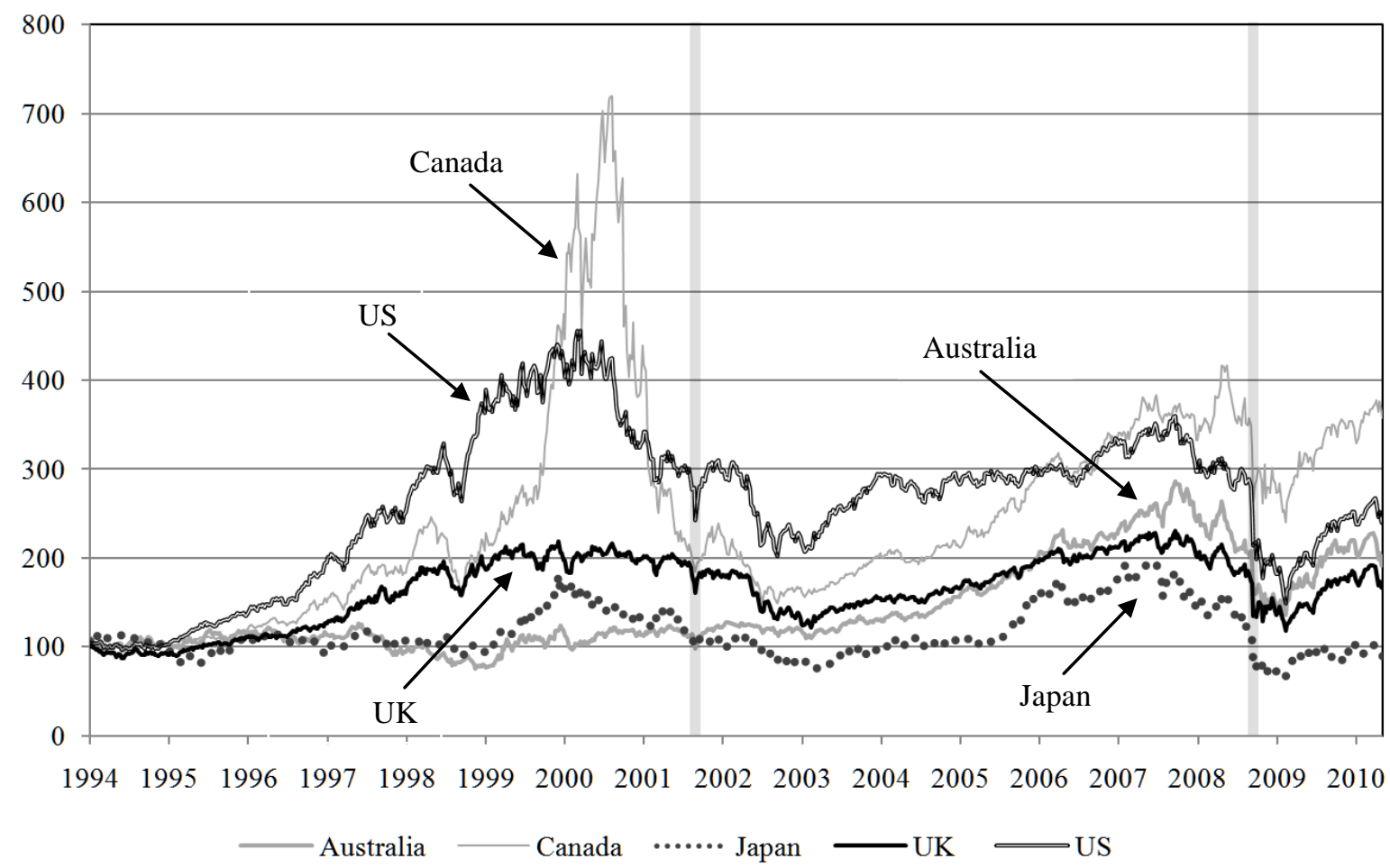

Figure 1 Movement of SRI Market Indices from 1994 to 2010 

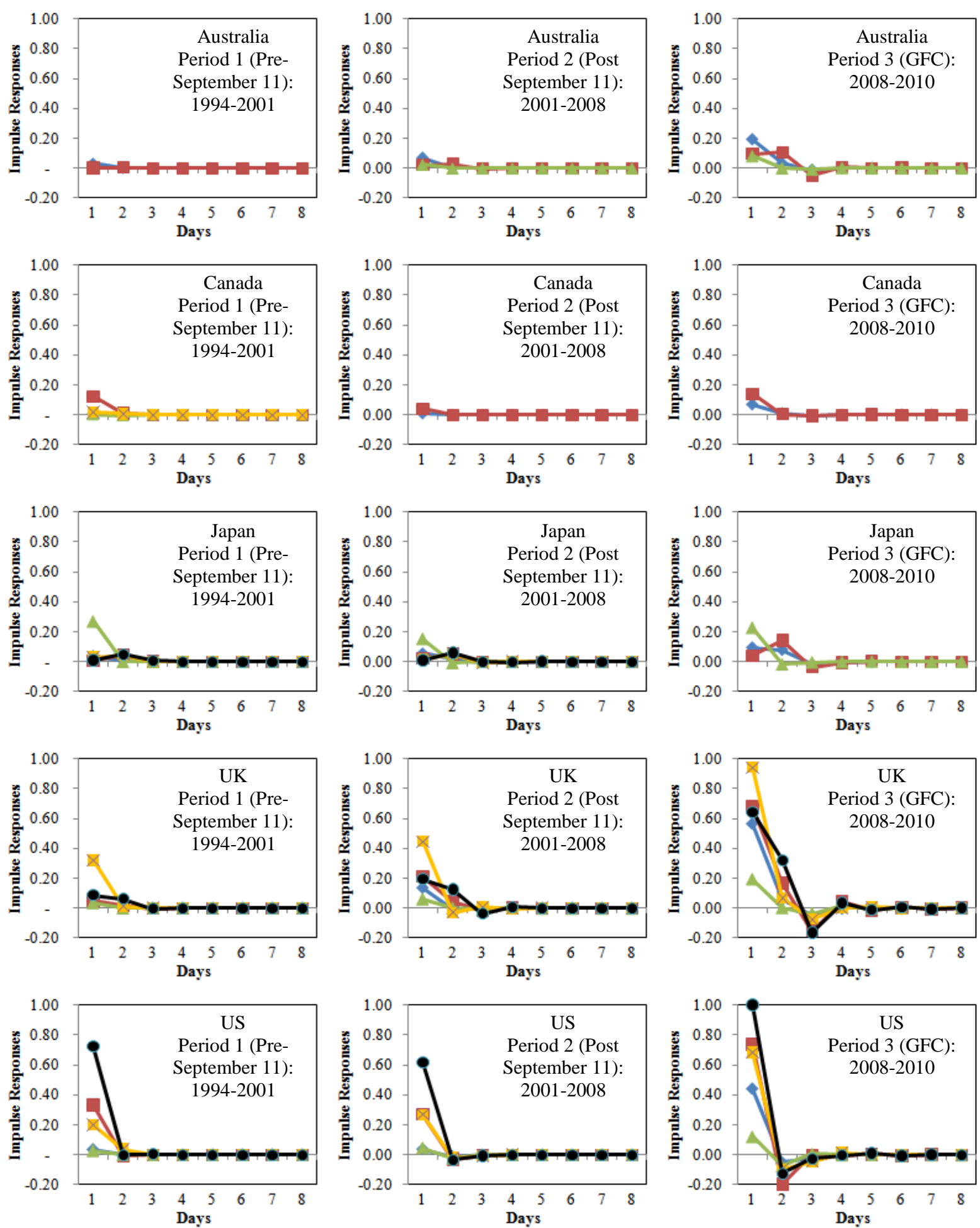

\section{$\leadsto$-Australia - -Canada $\_$Japan $-\mathbb{-}$-UK $\rightarrow$-US}

Figure 2 Impulse responses for the SRI markets 